\title{
DECOMPOSITION OF COVER CROP MULCH AND WEED CONTROL UNDER A NO-TILL SYSTEM FOR ORGANIC MAIZE
}

\author{
DECOMPOSIÇÃO DA PALHADA E CONTROLE DE PLANTAS DANINHAS EM \\ PLANTIO DIRETO ORGÂNICO DE MILHO
}

\begin{abstract}
Lamara Freitas BRITO ${ }^{1}$; João Carlos Cardoso GALVÃO ${ }^{1}$; Jeferson GIEHL ${ }^{1}$; Steliane Pereira COELHO' ${ }^{1}$; Silvane de Almeida CAMPOS $^{1}$; Tatiana Pires BARRELLA Tamara Rocha dos SANTOS ${ }^{3}$; Beatriz Ferreira MENDONÇA ${ }^{1}$; Edio Vicente de JESUS ${ }^{4}$

1. Universidade Federal de Viçosa, Campus Viçosa, Departamento de Fitotecnia, Viçosa, MG, Brasil. lamarabrito@ hotmail.com; 2. Universidade Federal de Viçosa, Campus Viçosa, Departamento de Educação, Viçosa, MG, Brasil; 3. Universidade Federal de Goiás, Escola de Agronomia, Goiânia, GO, Brasil; 4. Instituto Federal de Minas Gerais, Campus São João Evangelista, São João Evangelista, MG, Brasil.
\end{abstract}

\begin{abstract}
The decomposition dynamics of cover crop mulch influence the nutrient supply of successor crops and weed suppression. This is even more relevant in organic production systems, due to their limited use of chemical fertilizers and herbicides. As such, the aim of this study was to quantify biomass production, model the decomposition and $\mathrm{N}, \mathrm{P}$ and $\mathrm{K}$ release of the mulch of different cover crops, and assess the weed suppression of cover crops in the form of mulch and in consortium with organic maize. A randomized block design was used, with a 7x2 factorial scheme (7 cover crop management strategies and 2 cropping systems - maize in monoculture and intercropped with jack bean) and 4 replicates. The management practices that produced the most biomass were white lupine intercropped with black oat and the white lupine, black oat and sunflower monocultures. The use of cover crops did not differ from manual weeding in terms of weed biomass, but did affect the relative importance (RI) of nutgrass. Additionally, maize intercropped with jack bean reduced weed biomass in subsequent crop growth stages.
\end{abstract}

KEYWORDS: Lupinus albus. Avena strigosa. Helianthus annuus. Zea mays. Plant nutrition. Weed suppression.

\section{INTRODUCTION}

Organic farming combines traditional and conservation-oriented farming methods with modern agricultural technologies. It emphasizes crop rotation, biological pest control, plant and animal diversification, and enhanced soil quality through the use of compost and green manure (REGANOLD; WACHTER, 2016). In this context, cover crops are grown for non-commercial purposes and serve as green manure when incorporated into the soil (FAGERIA et al., 2005).

Cover crops have a number of important characteristics, including their rapid growth under sub-optimal conditions, ability to produce sufficient biomass to cover the soil, nitrogen-fixing capacity, deep root system, low mulch $\mathrm{C}: \mathrm{N}$ ratio, and the fact that no harmful substances are produced for the successor crop. Over time, they have evolved from being a tool in nitrogen management to increasing yield and sustainability in agroecosystems (FAGERIA et al., 2005) in addition to contributing to weed control in organic and agroecological production systems.
Organic farmers rely more heavily on cover crops as multifunctional management tools and value them as an ecosystem service. They are also willing to spend more on cover crop seeds (WAYMAN et al., 2016).

The production of mulch cover crops became popular with the adoption of the no-till, system, which is generally closely linked to herbicide use to desiccate cover crops and control weeds. However, agricultural extension agencies are working to disseminate the use of cover crops and no-till systems adapted to small farms, including strategies to reduce herbicide application, such as selecting cover crop species and using roller crimpers (ALTIERI et al., 2011).

In the Brazilian Cerrado region, low rainfall during the off-season results in low biomass production and hampers the adoption of no-till systems (MENEZES; LEANDRO, 2004). This significantly limits the growing season and means that irrigation is often required to establish cover crops in the off-season.

As such, the aim of this study was to quantify biomass production, model the decomposition and $\mathrm{N}, \mathrm{P}$ and $\mathrm{K}$ release of the mulch 
of different cover crops, and assess the weed suppression of cover crops in the form of mulch intercropped with organic maize.

\section{MATERIAL AND METHODS}

The study was carried out at an experimental station in Minas Gerais state, located at $20^{\circ} 45^{\prime} \mathrm{S}, 45^{\circ} 51^{\prime} \mathrm{W}$ and an altitude of $650 \mathrm{~m}$. The soil in the area is classified as red yellow argisol (EMBRAPA, 2013) and the climate is mesothermal, with average annual temperature and rainfall of 19.4 ${ }^{\circ} \mathrm{C}$ and $1,165 \mathrm{~mm}$, respectively (RAMOS et al., 2009) (Figure 1).

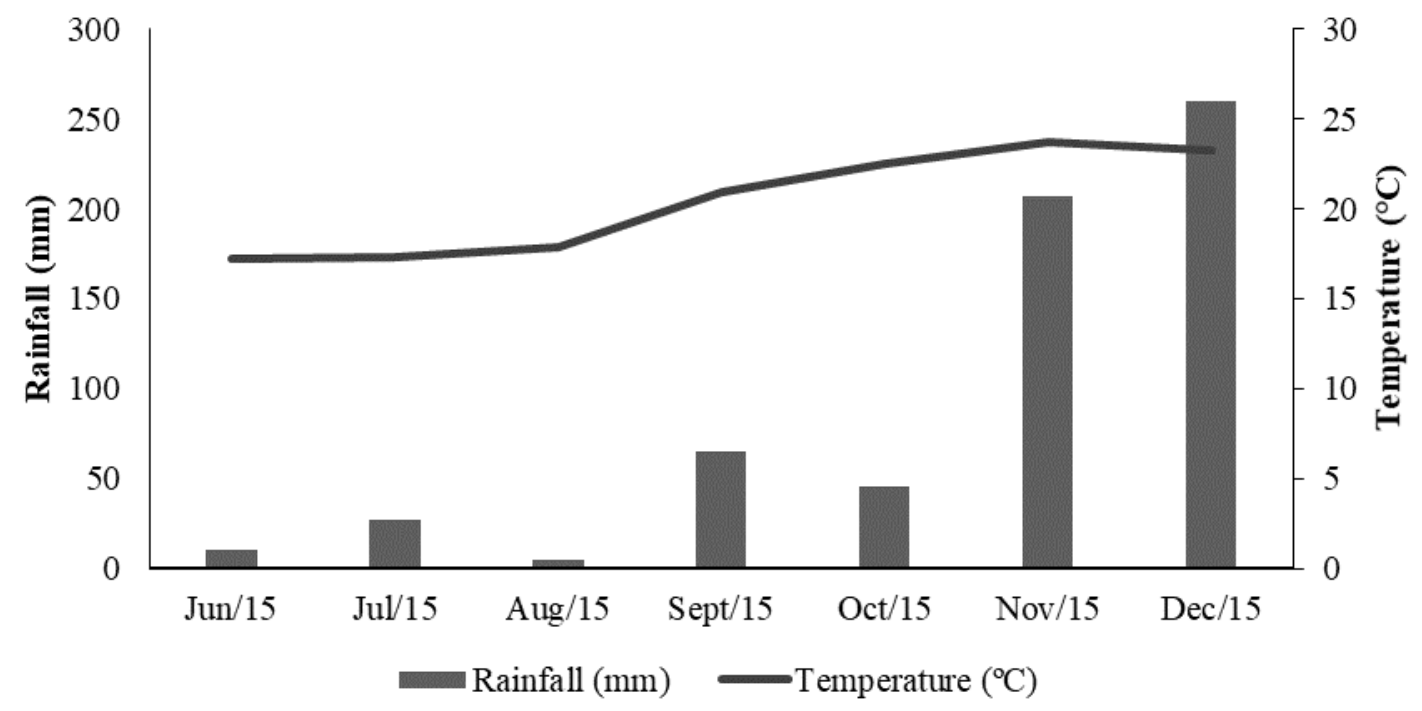

Figure 1. Meteorological data from the automated weather station located $20 \mathrm{~km}$ from the experimental area. June to December, 2015.

Prior to the experiment, soil samples were collected at a depth of $0-10 \mathrm{~cm}$, with the following results: $\mathrm{pH}$ in water $=5.70, \mathrm{P}=9.4 \mathrm{mg} \mathrm{dm}^{-3}, \mathrm{~K}=$ $350 \mathrm{mg} \mathrm{dm}^{-3}, \mathrm{Ca}=25 \mathrm{mmol}_{\mathrm{c}} \mathrm{dm}^{-3}, \mathrm{Mg}=13 \mathrm{mmol}_{\mathrm{c}}$ $\mathrm{dm}^{-3}, \mathrm{Al}^{3+}=0 \mathrm{mmol}_{\mathrm{c}} \mathrm{dm}^{-3}, \mathrm{H}+\mathrm{Al}=46.2 \mathrm{mmol}_{\mathrm{c}} \mathrm{dm}^{-}$ ${ }^{3}$, sum of bases $=47 \mathrm{mmol}_{\mathrm{c}} \mathrm{dm}^{-3}$, effective $\mathrm{CEC}=$ $47 \mathrm{mmol}_{\mathrm{c}} \mathrm{dm}^{-3}$, potential CEC $=93.2 \mathrm{mmol}_{\mathrm{c}} \mathrm{dm}^{-3}$, base saturation $=50 \%$, organic matter $=39.9 \mathrm{~g} \mathrm{~kg}^{-1}$ and remaining $\mathrm{P}=23.2 \mathrm{mg} \mathrm{L^{-1 }}$, measured in accordance with Silva (2009).

The experiment was carried out in the 2015/2016 growing season, under an organic maize no-till system, using a randomized block design in a 7 x 2 factorial scheme (7 cover crop management strategies and 2 cropping systems - maize in monoculture and intercropped with jack bean (Canavalia ensiformis), with four replicates. Cover crop management in the 2 cropping systems consisted of mulch from spontaneous plants, black oat, sunflower, white lupine and black oat (intercropped in rows), white lupine and black oat (intercropped by broadcasting), white lupine in monoculture and a control with no cover crop.

The cover crops were planted on June 28, 2015 and mowed on October 5, after flowering. The Embrapa 29 black oat (Avena strigosa) cultivar was sown by broadcasting at a density of $80 \mathrm{~kg} \mathrm{ha}^{-1}$ of seeds. The Catissol 01 sunflower (Helianthus annuus) variety was planted in rows spaced $0.90 \mathrm{~m}$ apart, reaching a population of 55,000 plant ha-1 after thinning. The spontaneous plants that emerged from the soil seed bank were kept as plant cover in the corresponding treatment. White lupine (Lupinus albus) in monoculture was sown by broadcasting at a density of $85 \mathrm{~kg} \mathrm{ha}^{-1}$. Black oat intercropped with white lupine was planted in rows spaced $0.33 \mathrm{~m}$ apart at densities of $30 \mathrm{~kg} \mathrm{ha}^{-1}$ and $40 \mathrm{~kg} \mathrm{ha}^{-1}$, respectively. Thirty percent more seeds were used in the black oat/white lupine treatment with broadcast seeding. No base or topdressing fertilizers were applied to cover crops and additional irrigation was performed for plant establishment.

The experimental unit $\left(19.2 \mathrm{~m}^{2}\right)$ consisted of six 4-meter-long rows of maize spaced $0.80 \mathrm{~m}$ apart. The maize variety used was $A L$ Bandeirante, characterized by tall plants with a normal growth cycle. Maize seeds were sown 10 days after the cover crops were mowed, at a planting density of 50,000 plants $\mathrm{ha}^{-1}$. Jack bean was manually planted in the maize row at the same time as maize, at a density of five plants per meter. Additional 
irrigation was performed in the early stages of maize cultivation.

At phenological stage V4, i.e., four fully expanded maize leaves, $40 \mathrm{~m}^{3} \mathrm{ha}^{-1}\left(\sim 12 \mathrm{Mg} \mathrm{ha}^{-1}\right)$ of organic compost was applied next to the row without incorporation. The results of chemical analysis of the compost (dry matter), conducted according to the methodology described by Silva (2009), were as follows: organic carbon $=106.1 \mathrm{~g}$ $\mathrm{kg}^{-1}$; total $\mathrm{N}=11 \mathrm{~g} \mathrm{~kg}^{-1} ; \mathrm{P}=3.8 \mathrm{~g} \mathrm{~kg}^{-1} ; \mathrm{K}=12 \mathrm{~g} \mathrm{~kg}^{-}$ 1; $\mathrm{Ca}=9.4 \mathrm{~g} \mathrm{~kg}^{-1} ; \mathrm{Mg}=4.2 \mathrm{~g} \mathrm{~kg}^{-1} ; \mathrm{S}=5.3 \mathrm{~g} \mathrm{~kg}^{-1}$; $\mathrm{Zn}=158 \mathrm{mg} \mathrm{kg}^{-1} ; \mathrm{Fe}=37686 \mathrm{mg} \mathrm{kg}^{-1} ; \mathrm{Mn} 239 \mathrm{mg}$ $\mathrm{kg}^{-1} ; \mathrm{Cu}=68 \mathrm{mg} \mathrm{kg}^{-1} ; \mathrm{B}=13.1 \mathrm{mg} \mathrm{kg}^{-1}, \mathrm{Na}=1.8 \mathrm{~g}$ $\mathrm{kg}^{-1}$ and $\mathrm{pH} 8.83$.

In order to determine cover crop biomass production, a $0.25 \times 0.25 \mathrm{~m}$ grid was randomly placed in the plot four times, except for the sunflower crop, in which all the whole plants within one linear meter were collected. The plants were cut at ground level and dried in an oven at $70{ }^{\circ} \mathrm{C}$ for 72 h.

Nutrient cycling was assessed in experimental units consisting of $2 \mathrm{~mm}$ mesh $0.25 \mathrm{x}$ $0.25 \mathrm{~m}$ litterbags (REZENDE et al., 1999, AMADO et al., 2002), filled with $60 \mathrm{~g}$ of fresh matter fragments of the respective mulch material. Next, the bags were placed in the field in the respective experimental units from which the material originated. Assessments were conducted immediately after cover crop plants were cut, and 15, 30, 45, and 60 days after plant residue decomposition.

The litterbags were collected and dried in an oven to determine the remaining dry matter and nutrient contents. The mulch was ground in a Wiley mill and submitted to chemical analysis in the laboratory to determine $\mathrm{N}, \mathrm{P}$ and $\mathrm{K}$ content. Nitrogen content was analyzed using Kjeldahl's method, and $\mathrm{P}$ and $\mathrm{K}$ were determined by nitricperchloric digestion with blue molybdenum spectrophotometry and flame photometry, respectively, as described in Silva (2009). The residual nutrient content was calculated by multiplying the remaining biomass and nutrient concentration in the biomass.

A $0.25 \times 0.25 \mathrm{~m}$ grid was used to assess the weed population at 15,30 and 90 days after emergence (stages V2, V5 and R4), with three subsamples collected from the experimental unit at each assessment. The weeds were cut at ground level, separated by species, counted and dried in an oven at $70{ }^{\circ} \mathrm{C}$ for $72 \mathrm{~h}$. The relative importance (RI) of each species was determined based on plant weight and number, in accordance with Pitelli (2000). When the maize plants reached stages V3 and V6, weeding was performed with a backpack brushcutter. Maize grown without a cover crop was manually weeded before planting and at the same phenological stages.

Data were submitted to analysis of variance ( $\mathrm{p}<0.05$ ) and means compared using Tukey's test (when appropriate) and ASSISTAT software (SILVA \& AZEVEDO, 2016). Regression adjustment was performed for remaining biomass and nutrient concentration in the mulch, using GENES software (CRUZ, 2016) and a simple negative exponential model (THOMAS AND ASAWAKA, 1993; ROSSI et al., 2013), as follows: (Eq. 1)

$$
X_{t}=X_{0} e^{-h t}
$$

where " $\mathrm{X}_{\mathrm{t}}$ " is the biomass or nutrient concentration at " $\mathrm{t}$ " days; " $\mathrm{X}_{\mathrm{o}}$ " the initial biomass or nutrient concentration; and "k" the decomposition/release constant.

The half-life time (T1/2), i.e., time required to decompose $50 \%$ of the biomass or release $50 \%$ of the nutrient, was calculated using the " $\mathrm{k}$ " values of the mathematical model.

(Eq. 2)

$$
T_{1 / 2}=\frac{m 0_{i}}{k}
$$

\section{RESULTS AND DISCUSSION}

As expected, maize grown in monoculture or intercropped with jack bean did not influence mulch decomposition or its nutrient release rate. The cover crop management systems that produced the most biomass were white lupine in monoculture and intercropped with black oat (in rows and by broadcasting) and sunflower (Table 1). This can be explained by the size of white lupine and sunflower plants and their adaptation to winters with higher temperatures (WUTKE et al., 2014). Black oat, a smaller species with superior tillering at low temperatures, produced an intermediate amount of biomass (MASCARENHAS; WUTKE, 2014).

The spontaneous plant cover crop system produced the smallest amount of biomass. Although spontaneous plants have several functions, including soil protection, allowing them to dominate an area can increase the soil seed bank, hampering the management of cash crops such as maize. Moreover, cover crops introduced to the area do not become weeds.

A major advantage of using legumes as cover crops is $\mathrm{N}$ addition through biological fixation. In this case, although white lupine monoculture and intercropping did not differ in terms of biomass production, higher $\mathrm{N}$ levels (230 $\mathrm{kg} \mathrm{ha}^{-1}$ ) were recorded for the monoculture, whereas intercropping recycled $175 \mathrm{~kg} \mathrm{ha}^{-1}$ of $\mathrm{N}$. 
Table 1. Estimated biomass production, nutrient recycling and $\mathrm{C}: \mathrm{N}$ ratio of six cover crop management strategies in Minas Gerais, 2015.

\begin{tabular}{lllllllllll}
\hline & Biomass & & N & & P & & K & & \multicolumn{2}{c}{ C:N } \\
& & - & ---- & & & -- \\
\hline Spontaneous plants & 4940 & $\mathrm{~b}^{2}$ & 46 & $\mathrm{~b}$ & 50 & $\mathrm{ab}$ & 201 & $\mathrm{ab}$ & 47 & $\mathrm{ab}$ \\
Black oat & 7020 & $\mathrm{ab}$ & 46 & $\mathrm{~b}$ & 33 & $\mathrm{~b}$ & 97 & $\mathrm{~b}$ & 68 & $\mathrm{a}$ \\
Sunflower & 9012 & $\mathrm{a}$ & 126 & $\mathrm{ab}$ & 75 & $\mathrm{a}$ & 251 & $\mathrm{a}$ & 34 & $\mathrm{bc}$ \\
BO + WL (rows) & 9360 & $\mathrm{a}$ & 174 & $\mathrm{a}$ & 61 & $\mathrm{ab}$ & 169 & $\mathrm{ab}$ & 25 & $\mathrm{c}$ \\
BO + WL (broadcasting) & 9320 & $\mathrm{a}$ & 176 & $\mathrm{a}$ & 43 & $\mathrm{ab}$ & 128 & $\mathrm{~b}$ & 32 & $\mathrm{bc}$ \\
White lupine & 9800 & $\mathrm{a}$ & 230 & $\mathrm{a}$ & 35 & $\mathrm{~b}$ & 96 & $\mathrm{~b}$ & 19 & $\mathrm{c}$ \\
\hline Mean & 8242 & & 133 & & 49 & & 157 & & 37 & \\
CV $(\%)$ & 28 & & 56 & & 45 & & 48 & & 38 & \\
\hline
\end{tabular}

${ }^{1}$ Calculations assumed $42 \% \mathrm{C}$ in the biomass; ${ }^{2}$ Means followed by the same letter do not differ statistically according to Tukey's test at $5 \% ; \mathrm{BO}=$ Black oat; $\mathrm{WL}=$ white lupine.

Legume intercropping with grasses produces mulch with a higher $\mathrm{C}: \mathrm{N}$ ratio than legumes alone. However, the $\mathrm{C}: \mathrm{N}$ ratio of the intercropping systems in this experiment remained at around 30, with decomposition rates similar to those recorded in the legume monoculture (Figure 2).

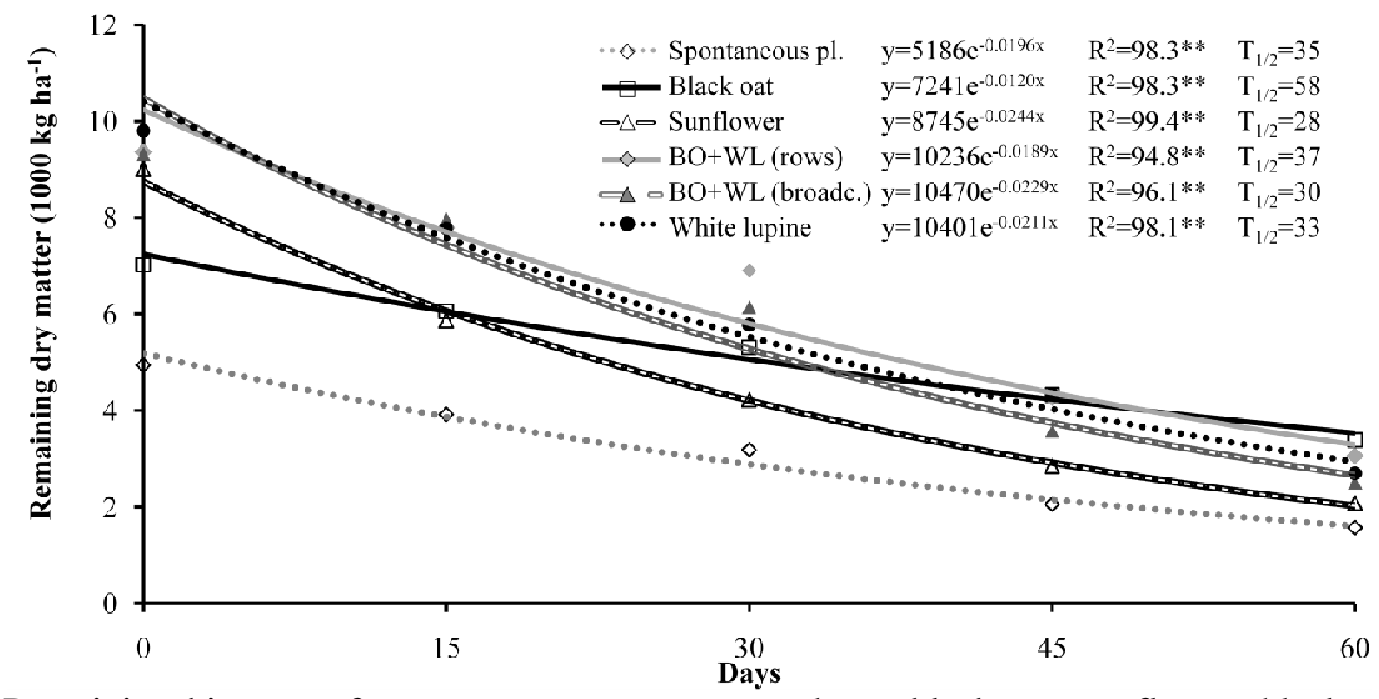

Figure 2. Remaining biomass of cover crops: spontaneous plants, black oat, sunflower, black oat + white lupine (BO+WL) intercropped in rows and by broadcasting, and white lupine in monoculture. Minas Gerais - Brazil, 2015.

Sunflower exhibited one of the highest decomposition rates. The plant parts of this species vary significantly in terms of their decomposition rate, with leaves decomposing quickly while the more lignified stem takes longer. According to Zobiole et al. (2010), the leaves and stem contain $39.9 \mathrm{~g} \mathrm{~kg}^{-1}$ and $7.7 \mathrm{~g} \mathrm{~kg}^{-1}$ of $\mathrm{N}$, respectively, at $\mathrm{R} 6$ (final flowering).

Although sunflower does not contribute to biological $\mathrm{N}$ fixation, as a non-leguminous plant it exhibits high $\mathrm{N}$ scavenging capacity, as reported by Fageria et al. (2005). Their high biomass production and $\mathrm{N}$ absorption mean sunflowers enhance nutrient cycling and reduce $\mathrm{N}$ losses.

Black oat provides little $\mathrm{N}$ for the successor crop, largely because, as a grass, it contains less nitrogen. Additionally, the high $\mathrm{C}: \mathrm{N}$ ratio of the mulch can immobilize $\mathrm{N}$ from the soil. Even the spontaneous plants showed a higher $\mathrm{N}$ concentration when compared to black oat, but their lower biomass production resulted in less recycling of this nutrient. Moreover, the cover crops with the highest $\mathrm{C}: \mathrm{N}$ ratio took longer to release $50 \%$ of their $\mathrm{N}$ (Figure 2). 


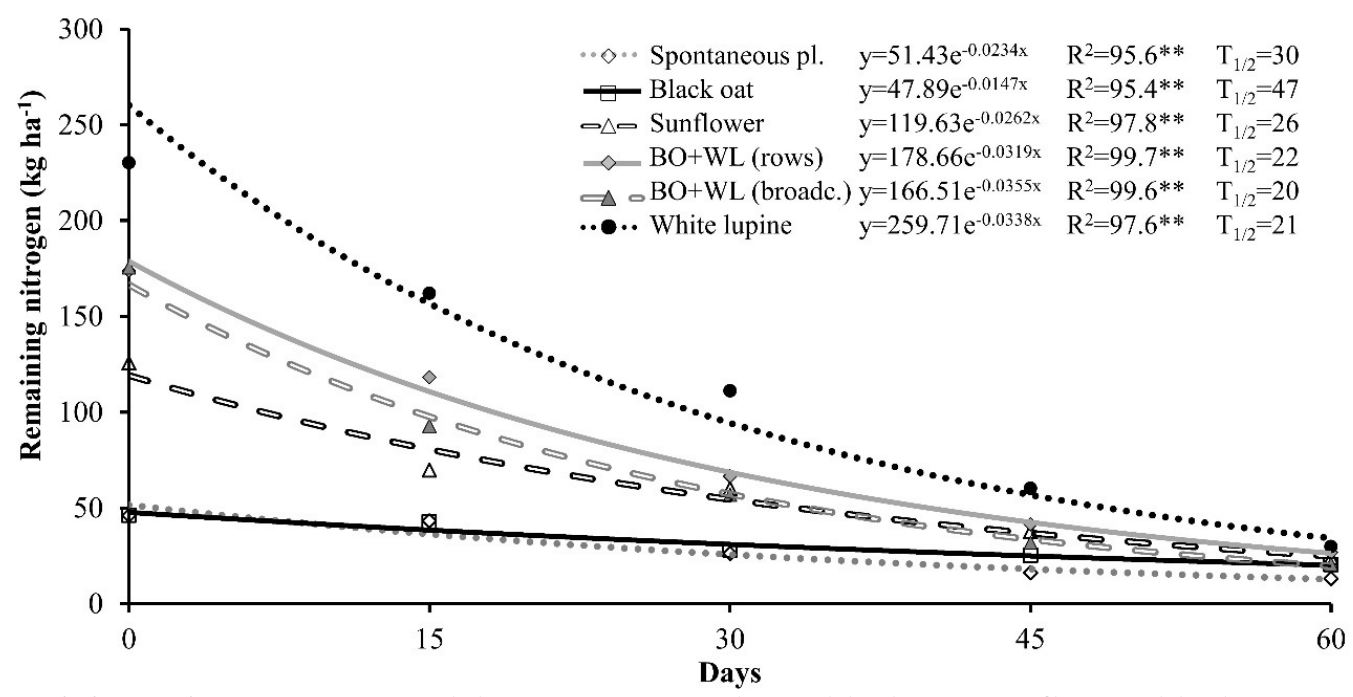

Figure 3. Remaining $\mathrm{N}$ in cover crop mulch: spontaneous plants, black oat, sunflower, black oat + white lupine $(\mathrm{BO}+\mathrm{WL})$ intercropped in rows and by broadcasting, and white lupine in monoculture. Minas Gerais Brazil, 2015.

Sunflower also stood out as the crop that recycled the most $\mathrm{P}$ and $\mathrm{K}$ (75 and $250 \mathrm{~kg} \mathrm{ha}^{-1}$, respectively), while black oat contributed with smaller amounts (33 and $97 \mathrm{~kg} \mathrm{ha}^{-1}$, respectively).

With respect to $\mathrm{P}$ release in the cash crop, this nutrient is typically less limiting to decomposition (GIACOMINI et al., 2003), resulting in lower P immobilization by microorganisms when compared to $\mathrm{N}$ and therefore higher $\mathrm{P}$ release rates (Figure 4). Unlike N, cover crop species had almost no influence on $\mathrm{P}$ and $\mathrm{K}$ release rates, with halflives ranging from 13 to 15 days and 8 to 11 days, respectively (Figure 5).

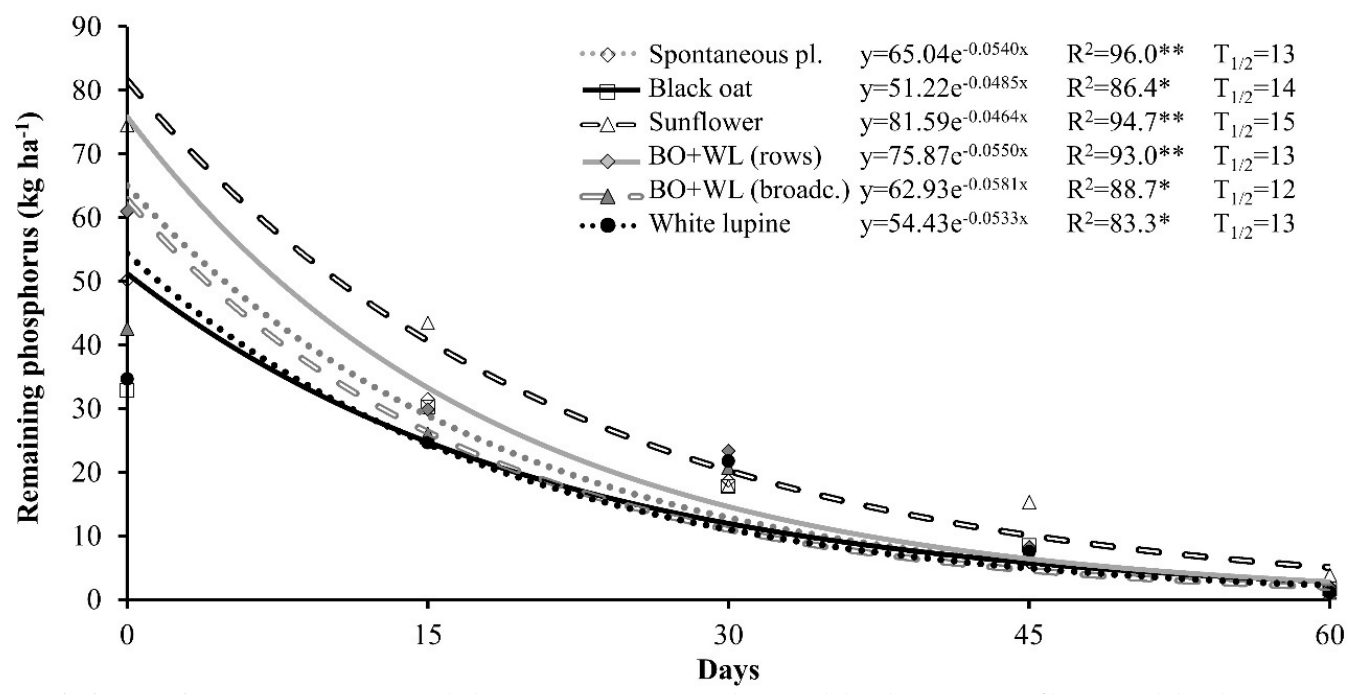

Figure 4. Remaining $P$ in cover crop mulch: spontaneous plants, black oat, sunflower, black oat + white lupine (BO+WL) intercropped in rows and by broadcasting, and white lupine in monoculture. Minas Gerais Brazil, 2015. 


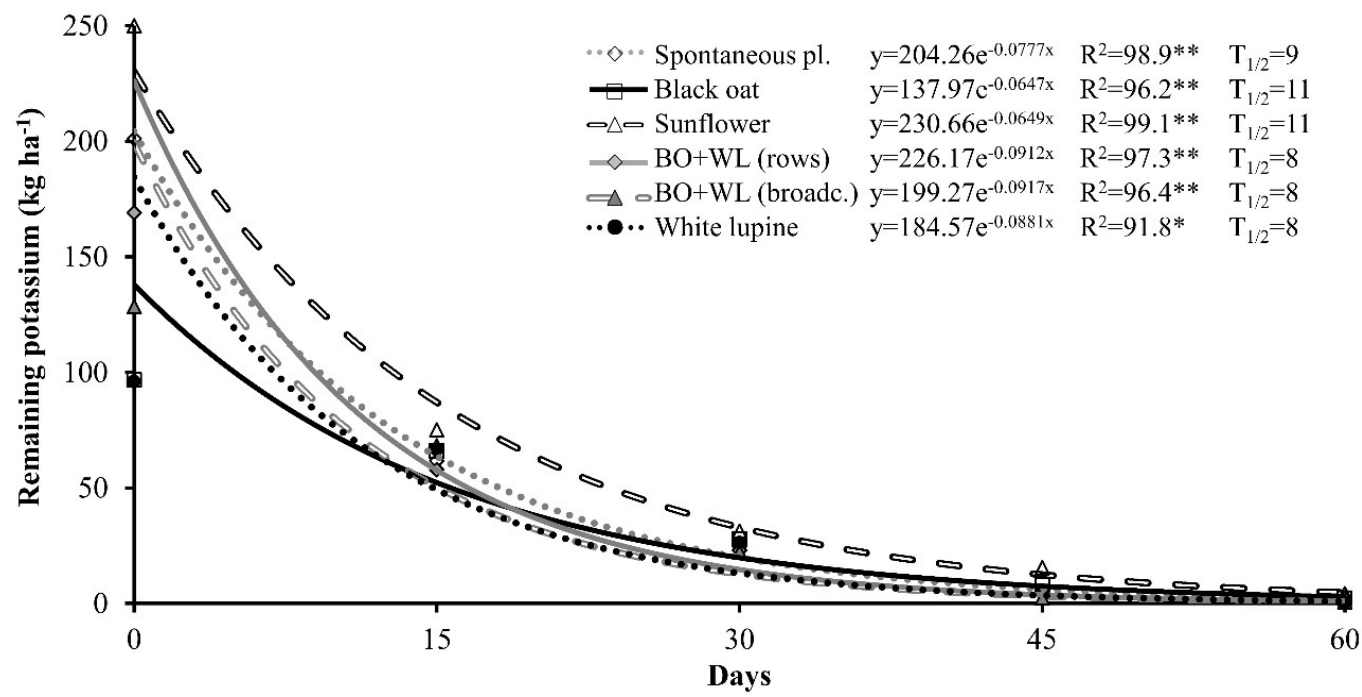

Figure 5. Remaining $\mathrm{K}$ in cover crop mulch: spontaneous plants, black oat, sunflower, black oat + white lupine $(\mathrm{BO}+\mathrm{WL})$ intercropped in rows and by broadcasting, and white lupine in monoculture. Minas Gerais Brazil, 2015.

Although black oat produced an intermediate amount of biomass, it had a longer half-life and lower decomposition rate, making it similar to white lupine during the critical period of weed competition with maize. Aita and Giacomini (2003) reported $81 \%$ biomass remaining on the soil for black oat and only $57 \%$ for common vetch (Fabaceae) at the end of the first month.

In regarding to weed biomass (Table 2), there was no difference between the cover crop management strategies in any of the maize phenological stages. Thus, mulch combined with mowing provided the same level of weed control as manual weeding, although the weed species composition differed. While on one hand manual weeding eradicates almost all the plants, the resulting uncovered soil favors the germination of new seeds and rapid regrowth of weeds such as nutgrass (Cyperus rotundus). Additionally, although mulch provides soil cover, it does not last long because $50 \%$ of the mulch biomass decomposed between 28 and 58 days, depending on the species.

Table 2. Estimated weed biomass as a function of maize growth stage, cover crop management and cropping system. Minas Gerais - Brazil, 2015.

\begin{tabular}{|c|c|c|c|}
\hline \multirow{2}{*}{ Cover crop management } & \multicolumn{3}{|c|}{ Weed biomass $\left(\mathrm{g} \mathrm{m}^{-2}\right)$} \\
\hline & $\mathrm{V} 2$ & V5 & $\mathrm{R} 4$ \\
\hline Spontaneous plants & $34.3^{\mathrm{ns}}$ & $27.0^{\text {ns }}$ & $3.1^{\text {ns }}$ \\
\hline No cover crop & 16.1 & 14.5 & 3.5 \\
\hline Black oat & 29.5 & 18.6 & 4.7 \\
\hline Sunflower & 31.2 & 11.9 & 6.1 \\
\hline $\mathrm{BO}+\mathrm{WL}$ (rows) & 41.6 & 22.0 & 4.3 \\
\hline BO + WL (broadcasting) & 30.9 & 13.5 & 5.1 \\
\hline White lupine & 28.1 & 17.2 & 4.7 \\
\hline \multicolumn{4}{|l|}{ Cropping system } \\
\hline Maize monoculture & $34.1^{\mathrm{ns}}$ & $19.2^{\text {ns }}$ & $6.9 \mathrm{a}^{1}$ \\
\hline Intercropped with jack bean & 26.4 & 16.4 & $2.2 \mathrm{~b}$ \\
\hline Mean & 30.3 & 17.8 & 4.5 \\
\hline CV $(\%)$ & 65.2 & 67.9 & 129.2 \\
\hline
\end{tabular}

${ }^{1}$ Means followed by the same letter do not differ statistically according to the F-test at $5 \%$ probability; ${ }^{\text {ns }}$ not significant according to the F-test at $5 \%$ probability; $\mathrm{BO}=$ Black oat; $\mathrm{WL}=$ white lupine. 
Nutgrass obtained the highest RI\% at all the assessment times (Figure 6). In stage V2 of maize, nutgrass accounted for more than half of the relative importance, declining as the maize crop developed. This is due to the $\mathrm{C} 4$ metabolism of nutgrass, which loses its ability to compete when shaded by maize.

Among the cover crops studied, nutgrass showed the greatest relative importance in the management system with no cover crop, that is, more than $80 \%$ in stage V2. The absence of mulch favors nutgrass tuber budding (JAKELAITIS et al., 2003). Moreover, while manual weeding kills other plants, nutgrass quickly regrows. As such, in addition to being onerous, manual weeding benefits nutgrass growth and propagation.

Cover crop management did not influence biomass production in intercropping with Jack bean, which produced $2,730 \mathrm{~kg} \mathrm{ha}^{-1}$. This lowered weed biomass production in later maize growth stages. Thus, the combination of cover crop mulch and intercropping maize with jack is beneficial controlling weed populations control in maize crops.

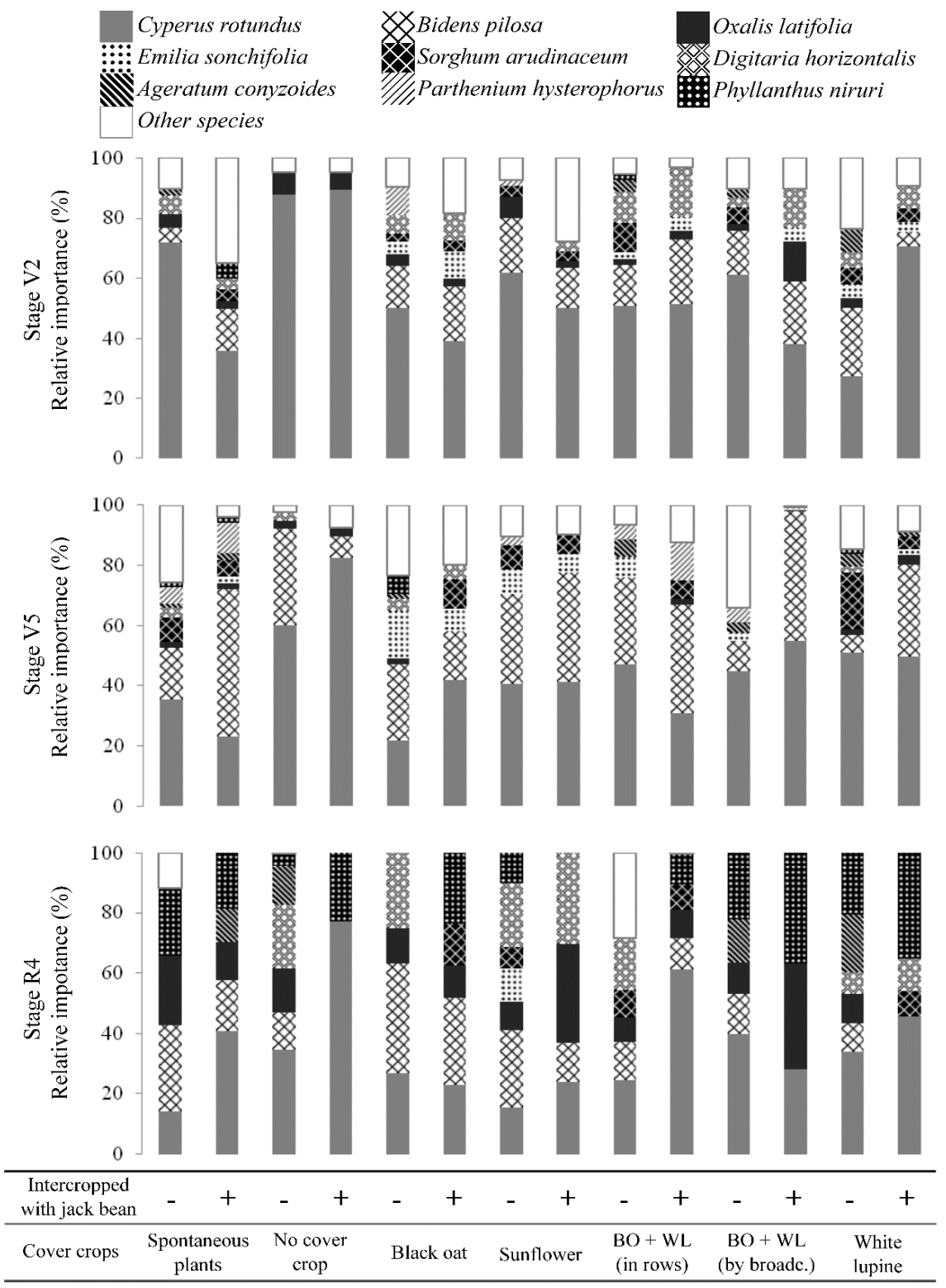

Figure 6. Relative importance of weeds in three maize phenological stages as a function of cover crop mulch management (spontaneous plants, black oat, sunflower, black oat + white lupine (BO+WL) intercropped in rows and by broadcasting, and white lupine in monoculture) and cropping system (with and without intercropping with jack bean). Minas Gerais - Brazil, 2015. 


\section{CONCLUSIONS}

White lupine and sunflower cover crops obtained the highest $\mathrm{N}$ recycling and decomposition rates, which resulted in the rapid decline of mulch soil covering.

While cover crop mulch suppresses weeds in the early maize growth stages, intercropping with jack bean contributes to weed control in the final stages. The combination of these two management practices improves weed control in no-till organic maize systems.

\section{ACKNOWLEDGMENTS}

The authors are grateful to the Coordenação de Aperfeiçoamento de Pessoal de Nível Superior (CAPES) and Conselho Nacional de Desenvolvimento Científico e Tecnológico (CNPq) for supporting this study. This study was financed in part by the Coordenação de Aperfeiçoamento de Pessoal de Nível Superior - Brasil (CAPES) Finance Code 001 .

RESUMO: A dinâmica de decomposição da palhada de plantas de cobertura influencia o suprimento de nutrientes para a cultura sucessora e a supressão de plantas daninhas. Desse modo, o objetivo deste estudo foi quantificar a produção de biomassa e de modelar a decomposição e liberação de N, P e K da palhada de diferentes plantas de cobertura, assim como, avaliar a supressão de plantas daninhas por plantas de cobertura na forma de palhada e em consórcio com milho orgânico. O experimento foi realizado em esquema fatorial 7 x 2 ( 7 tipos de manejos de planta de cobertura e 2 sistemas de cultivo - milho em monocultivo e consorciado com feijão-de-porco) em blocos ao acaso com 4 repetições. Os manejos que produziram a maior biomassa foram os consórcios de tremoço branco e aveia preta, além dos monocultivos de tremoço branco, aveia preta e girassol. Os manejos de planta de cobertura não se diferenciaram do manejo com capina manual para biomassa de plantas daninhas, porém afetaram a importância relativa da tiririca. Já o consórcio de milho com feijão-deporco diminuiu a biomassa de plantas daninhas em estádios avançados da cultura.

PALAVRAS CHAVE: Lupinus albus. Avena strigosa. Helianthus annuus. Nutrição vegetal. Supressão de plantas daninhas

\section{REFERENCES}

AITA, C.; GIACOMINI, S. J. Decomposição e liberação de nitrogênio de resíduos culturais de plantas de cobertura de solo solteiras e consorciadas. Revista Brasileira de Ciência do Solo, Viçosa, v. 27, n. 1, p. 601612, 2003. http://dx.doi.org/10.1590/S0100-06832003000400004

ALTIERI, M. A.; LANA, M. A.; BITTENCOURT, H. V.; KIELING, A. S.; COMIN, J. J.; LOVATO, P. E. Enhancing crop productivity via weed suppression in organic no-till cropping systems in Santa Catarina, Brazil. Journal of Sustainable Agriculture, v. 35, n. 1, p. 855-869, 2011. http://dx.doi.org/10.1080/10440046.2011.588998

AMADO, T. J. C.; MIELNICZUK, J.; AITA, C. Recomendação de adubação nitrogenada para o milho no RS e SC adaptada ao uso de culturas de cobertura do solo, sob plantio direto. Revista Brasileira de Ciência do Solo, Viçosa, v. 26, n. 1, p. 241-248, 2002. http://dx.doi.org/10.1590/S0100-06832002000100025

CRUZ, C. D. Genes Software - extended and integrated with the R, Matlab and Selegen. Acta Scientiarum. Agronomy, Maringá, v. 38, n. 4, p. 547-552, 2016. http://dx.doi.org/10.4025/actasciagron.v38i3.32629

EMBRAPA - Empresa Brasileira de Pesquisa Agropecuária. Sistema brasileiro de classificação de solos. 3.ed. Brasília - DF: EMBRAPA. 2013, 353 p.

FAGERIA, N. K.; BALIGAR, V. C.; BAILEY, B. A. Role of cover crops in improving soil and row crop productivity. Communications in Soil Science and Plant Analisys, v. 36, n. 1, p. 2733-2757, 2005. http://dx.doi.org/10.1080/00103620500303939 
GIACOMINI, A. J.; AITA, C., HÜBNER, A. P.; LUNKES, A.; GUIDINI, E.; AMARAL, E. B. Liberação de fósforo e potássio durante a decomposição de resíduos culturais em plantio direto. Pesquisa Agropecuária Brasileira, Brasília, v. 38, n. 9, p. 1097-1104, 2003. http://dx.doi.org/10.1590/S0100-204X2003000900011

JAKELAITIS, A.; FERREIRA, L. R.; SILVA, A. A.; AGNES, E. L.; MIRANDA, G. V.; MACHADO, A. F. L. Efeitos de sistemas de manejo sobre a população de tiririca. Planta Daninha, Viçosa, v. 21, n. 1, p. 89-95, 2003. http://dx.doi.org/10.1590/S0100-83582003000100011

MASCARENHAS, H. A. A.; WUTKE, E. B. Adubação, nutrição e fatores climáticos limitantes ao desenvolvimento dos adubos verdes. In: LIMA FILHO, O. F.; AMBROSANO, E. J.; ROSSI, F.; CARLOS, J. A. D. (ed.) Adubação verde e plantas de cobertura no Brasil: fundamentos e práticas. Brasília - DF: Embrapa. 2014, p. 198-224.

MENEZES, L. A. S.; LEANDRO, W. M. Avaliação de espécies de cobertura do solo com potencial de uso em sistemas de plantio direto. Pesquisa Agropecuária Tropical, Goiânia, v. 34, n. 3, p. 173-180, 2004. https://www.revistas.ufg.br/pat/article/view/2311

PITELLI, R. A. Estudos fitossociológicos em comunidades infestantes de agroecossistemas. Jornal Consherb, São Paulo, v. 1, n. 2, p. 1-7, 2000.

RAMOS, A. M.; SANTOS, L. A. R.; FORTES, L. T. G. Normais climatológicas do Brasil, 1961-1990. Brasília - DF: INMET. 2009, 465 p.

REGANOLD, J. P.; WACHTER, J. M. Organic agriculture in the twenty-first century. Nature plants, v. 2, n. 1, p. 1-8, 2016. http://dx.doi.org/10.1038/nplants.2015.221

REZENDE, C. P.; CANTARUTTI, R.B.; BRAGA, J. M.; GOMIDE, J. A.; PEREIRA, J. M.; FERREIRA, E.; TARRÉ, R.; MACEDO, R.; ALVES, B. J. R.; URQUIAGA, S.; CADISCH, G.; GILLER, K. E.; BODDEY, R. M. Litter deposition and disappearance in Brachiaria pastures in the Atlantic Forest region of South of Bahia, Brazil. Nutrient Cycling in Agroecosystems, v. 54, n. 2, p. 99-112, 1999.

http://dx.doi.org/10.1023/A:1009797419216

ROSSI, C. Q.; PEREIRA, M. G.; GIACOMO, S. G.; BETTA, M.; POLIDORO, J. C. Litter decomposition and nutrient release from Brachiaria, Sorghum and soybean in no-tillage areas in the Cerrado region, Goiás. Semina: Ciências Agrárias, Londrina, v. 34, n. 4, p. 1523-1534, 2013. http://dx.doi.org/10.5433/1679$0359.2013 \mathrm{v} 34 \mathrm{n} 4 \mathrm{p} 1523$

SILVA, F. C. (Ed.) Manual de análise de solos, plantas e fertilizantes, $2^{\mathrm{a}}$ ed. Brasília - DF: Embrapa Informação Tecnológica. 2009, 627 p.

SILVA, F. A. S.; AZEVEDO, C. A. V. The Assistat Software Version 7.7 and its use in the analysis of experimental data. African Journal of Agricultural Research, v. 11, n. 39, p. 3733-3740, 2016. http://doi.org/10.5897/AJAR2016.11522

THOMAS, R. J.; ASAWAKA, N. M. Decomposition of leaf litter from tropical forage grasses and legumes. Soil Biology and Biochemistry, v. 25, n. 10, p. 1351-1361, 1993. https://doi.org/10.1016/00380717(93)90050-L

WAYMAN, S.; KUCEK, L. K.; MIRSKY, S. B.; ACKROYD, V.; CORDEAU, S.; RYAN, M. R. Organic and conventional farmers differ in their perspectives on cover crop use and breeding. Renewable Agriculture and Food Systems, v. 32, n. 4, p. 376-385, 2016. https://doi:10.1017/S1742170516000338 
WUTKE, E. B.; CALEGARI, A.; WILDNER, L. P. Espécies de adubos verdes e plantas de cobertura e recomendações para seu uso. In: LIMA FILHO, O. F.; AMBROSANO, E. J.; ROSSI, F.; CARLOS, J. A. D. (ed.) Adubação verde e plantas de cobertura no Brasil: fundamentos e práticas. Brasília - DF: Embrapa. 2014, p. 59-167.

ZOBIOLE, L. H. S.; CASTRO, C.; OLIVEIRA, F. A.; OLIVEIRA JUNIOR, A. Marcha de absorção de macronutrientes na cultura do girassol. Revista Brasileira de Ciência do Solo, Viçosa, v. 34, n. 1, p. 425-433, 2010. http://dx.doi.org/10.1590/S0100-06832010000200016 